\title{
Summary of: Cleaning endodontic files in a washer disinfector
}

\section{FULL PAPER DETAILS}

${ }^{1}$ Postgraduate Student in Endodontics; ${ }^{2 *}$ Senior Lecturer in Primary Dental Care; ${ }^{3}$ Senior Lecturer in Restorative Dentistry; School of Dentistry, The University of Manchester, Higher Cambridge Street, Manchester M15 6FH

${ }^{*}$ Correspondence to: Dr A. C. Mellor

Email: tony.mellor@manchester.ac.uk

Online article number E17

Refereed Paper - accepted 21 November 2007

DOI: $10.1038 /$ sj.bdj.2008.411

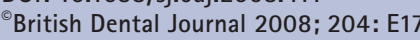

\begin{abstract}
Aims The aim of this study was to compare the cleanliness of endodontic files that had been cleaned in a washer disinfector according to the file holding mechanism within the machine. Methodology Selected canals of extracted teeth were filed with new, unused files. One set of files (size 15 to 40) was used for each canal. A total of 192 files were used for cleaning and shaping. The files were divided into three groups. The first group was a control group containing 30 files, which were not cleaned in the washer disinfector. The second and the third groups were the experimental groups with 81 files in each group. These files were cleaned in the washer disinfector using different holding mechanisms (file holder or cleaning basket) for each group. The files were examined for visible debris under a light microscope at x45 magnification. Results None of the 162 cleaned files were totally free of organic debris. Comparison of the debris scores in the two experimental groups showed that the files in the cleaning basket group were significantly cleaner than those in the file holder group. The files in both test groups were significantly cleaner than those in the control group. Conclusions Endodontic files cannot be totally cleaned using a washer disinfector alone. The instrument holding mechanism within the machine has a significant effect on the cleanliness of the files after one intensive cleaning cycle.
\end{abstract}

\section{EDITOR'S SUMMARY}

How clean is clean? How safe is safe? We come again to the question of risk, which in turn is about balancing likelihoods, responsibilities and consequences.

I was corresponding recently with a practitioner who had been in practice for many years during which he had seen the change from dry heat sterilisation, through autoclaves and now to washer-disinfectors. During that time, providing tens of thousands of courses of treatment, to the best of his knowledge he had not had a single incident of cross infection. Contrast this, he stated with the current MRSA record of his local hospital.

Conversely, one has to argue that once we are aware of a risk, or a potential danger, then we cannot ignore it or pretend we don't know of it. This is especially so when we are in charge of the safety of others who place themselves trustingly in our hands. So it becomes a matter of putting the risk into a perspective and balancing it against cost, for example, and culpability. But if the cost of protecting against the risk is so high that it prevents the activity taking place then it is probably going to be to the detriment of the patient. Does it then become a risk worth taking? One might equally ask if the risk of driving in a car to attend an appointment is actually, or theoretically, greater than that of contracting vCJD through an un-sterile root canal file. Should all human activity therefore cease 'just in case'?

There is no one answer but as pragmatic people we look for practical and reasonable solutions that allow treatment to continue, safety to be provided and a living to be earned. There is still some mileage to go. How theoretical is theoretical?
The full paper can be accessed from the $B D J$ website (www.bdj.co.uk), under 'Research' in the table of contents for Volume 204 issue 10.

Stephen Hancocks, Editor-in-Chief

DOI: 10.1038/sj.bdj.2008.412 


\section{TO ACCESS THE BDJ WEBSITE TO READ THE FULL PAPER:}

- BDA members should go to www.bda.org

- Do not login on the BDA home page, if you are already logged in, please log out.

- Then, in www.bda.org click on the link to the BDJ in the top left of the screen. A new window will open. If a new window fails to open please check the settings of any pop up blocker software that you have installed on your computer.

- You will now be asked to login with your BDA website login details which are on your BDA membership card.

- Once your details have been entered you will be transferred to the BDJ website. If your login does not work please contact the BDA Membership Department on 02075634550.

- If you are not able to access the article on the BDJ website there may be an issue with your system's firewall. If so, return to the BDA homepage and click on the link 'BDJ access problems' and follow the step by step guide.

\section{COMMENT}

When I first read this paper, I was struck with sympathy for the researchers. Having spent many hours on experimental design, formulating a hypothesis, carrying out the tests, statistical analysis and then finally writing up, all done well over a year ago, they were dealt a cruel blow by the Chief Dental Officer (CDO) for England, Dr Barry Cockcroft, in his revised advice of April 2007, stating that endodontic reamers and files should be treated as single use instruments. The question of whether a washer-disinfector can actually sterilise endodontic files, instantly became a non-issue to dental practitioners in the UK.

It is useful, however, to take a step back and review this research for what it tells us about endodontic instrument sterilisation in this country and others. The advice given by the CDO was in the context of variant Creutzfeldt-Jakob Disease (vCJD). The particular problem with vCJD is the ability of the prion to resist sterilisation, even on what are apparently clean surfaces. In fact, in the last Guidance from the Advisory Committee on Dangerous Pathogens and the Spongiform Encephalopathy Advisory Committee published in February 2007 on the Distribution of TSE (Transmissible Spongiform Encephalopathies) Infectivity in Human Tissues, prions could not be detected in human pulp, and the assumed level of infectivity was low.

This does make one wonder, therefore, why endodontic instruments were singled out for this level of control, the implication being that endodontic treatment carries a greater risk of vCJD transmissibility, with the knock on effect being further public disillusionment with root canal treatment.

The answer lies within the results of this research and other similar research. The simple fact that these researchers discovered once again is that it is pretty much impossible to sterilise endodontic files and reamers. 'None of the cleaned files were totally free of organic debris.' Irrespective of prions, great lumps of infected organic debris (bacteria, viruses, fungi) strongly adhere to the flutes of these instruments with little hope of removal, whether it be with manual brushing, a washer disinfector or vacuum sterilisers. If the debris cannot be removed, the instruments can never be sterile.

It is for this reason that I have to support the guidance of single use endodontic files and reamers, even with its undoubtedly severe consequences for the practice of NHS endodontics in this country. Cross infection control from all pathogens is of paramount concern. The right decision, from the CDO, just the wrong reason.

\section{R. S. Kahan, Specialist Endodontist,} Director of Endodontic Courses, Honorary Clinical Lecturer, University College London, Eastman CPD
IN BRIEF

- Washer disinfectors are becoming more commonly used in general dental practice.

- This work was designed to see if washer disinfectors could cope with the difficult challenge of cleaning small instruments with a complex surface structure.

- Although the files treated in the washer disinfector were generally clean, they were not totally free of organic debris.

- This work reinforces the view that endodontic files should be single-use only.

\section{AUTHOR QUESTIONS AND ANSWERS}

1. Why did you undertake this research?

This study is one of a series that we have undertaken in Manchester to examine the most effective ways of cleaning endodontic instruments prior to autoclave sterilisation. To date, we have examined the effect of time in an ultrasonic bath on the cleanliness of endodontic files ${ }^{1}$ and compared an ultrasonic bath and a washer disinfector in the cleaning of endodontic files. ${ }^{2}$ This study continues this work to examine whether the method of loading in the washer disinfector has an effect on cleanliness of endodontic files.

2. What would you like to do next in this area to follow on from this work?

Having examined the removal of organic debris from endodontic files using a washer disinfector, our next study will examine the removal of various endodontic dental materials from endodontic instruments using a washer disinfector.

1. Hovius M. Disinfection and sterilisation: the duties and responsibilities of dentists and dental hygienists. Int Dent J 1992; 42: 241-244.

2. Will R G, Ironside J W, Zeidler M et al. A new variant of Creutzfeldt-Jakob disease in the UK. Lancet 1996; 347: 921-925. 